See discussions, stats, and author profiles for this publication at: https://www.researchgate.net/publication/341534206

\title{
Evaluation of electrolytic reactor configuration for the regeneration of granular activated carbon saturated with methylene blue
}

Article in Journal of Environmental Chemical Engineering · May 2020

DOI: $10.1016 /$ j.jece.2020.104074

CITATION

1

4 authors, including:

Jawer David Acuña Bedoya

Autonomous University of Nuevo León

6 PUBLICATIONS 4 CITATIONS

SEE PROFILE

Nilson Marriaga-Cabrales

Universidad del Valle (Colombia)

38 PUBLICATIONS 105 CITATIONS

SEE PROFILE

Some of the authors of this publication are also working on these related projects:
READS

106

- Christian Eduardo Alvarez Pugliese

Universidad del Valle (Colombia)

11 PUblications 18 CITATIONS

SEE PROFILE

Diseño, Construcción y Montaje de una Planta Piloto para el Tratamiento Primario de Lixiviados por Electroflox View project

Electrolytic regeneration of granular activated carbon saturated with diclofenac View project 


\section{Journal Pre-proof}

Evaluation of electrolytic reactor configuration for the regeneration of granular activated carbon saturated with methylene blue

Jawer Acuña-Bedoya (Formal analysis) (Investigation) (Writing original draft) (Writing - review and editing), Jovannis A Comas-Cabrales (Methodology) (Investigation) (Writing - review and editing) (Visualization) (Software), Christian E Alvarez-Pugliese (Conceptualization) (Methodology) (Validation) (Writing - review and editing) (Data curation), Nilson Marriaga-Cabrales (Conceptualization) (Methodology) (Validation) (Supervision) (Project administration) (Funding acquisition) (Resources)

PII:

$$
\text { S2213-3437(20)30422-X }
$$

DOI: https://doi.org/10.1016/j.jece.2020.104074

Reference:

JECE 104074

To appear in: Journal of Environmental Chemical Engineering

Received Date: 17 March 2020

Revised Date: 11 May 2020

Accepted Date:

17 May 2020

Please cite this article as: Acuña-Bedoya J, A Comas-Cabrales J, Alvarez-Pugliese CE, Marriaga-Cabrales N, Evaluation of electrolytic reactor configuration for the regeneration of granular activated carbon saturated with methylene blue, Journal of Environmental Chemical Engineering (2020), doi: https://doi.org/10.1016/j.jece.2020.104074 
This is a PDF file of an article that has undergone enhancements after acceptance, such as the addition of a cover page and metadata, and formatting for readability, but it is not yet the definitive version of record. This version will undergo additional copyediting, typesetting and review before it is published in its final form, but we are providing this version to give early visibility of the article. Please note that, during the production process, errors may be discovered which could affect the content, and all legal disclaimers that apply to the journal pertain.

(C) 2020 Published by Elsevier. 


\section{Evaluation of electrolytic reactor configuration for the regeneration of granular}

\section{activated carbon saturated with methylene blue}

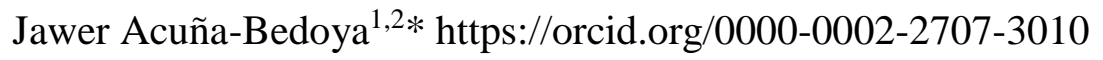

Jovannis A Comas-Cabrales ${ }^{1,3}$ https://orcid.org/0000-0003-4519-522X

Christian E Alvarez-Pugliese ${ }^{1}$ https://orcid.org/0000-0003-3177-0086

Nilson Marriaga-Cabrales ${ }^{1}$ https://orcid.org/0000-0002-5046-9371

${ }^{1}$ Department of Chemical Engineering, Universidad del Valle, Calle 13 \# 100-00, Cali, 76001, Colombia.

${ }^{2}$ Faculty of Chemical Sciences, Universidad Autónoma de Nuevo León, Ciudad Universitaria, Av. Universidad s/n. C. P. 66455, Nuevo León, México.

${ }^{3}$ Natural and Exact Sciences Department, Universidad de la Costa, Calle 58 \#55-66, Barranquilla, 080002, Colombia

*Corresponding authors email: jawer.acuna@ correounivalle.edu.co

\section{Graphical Abstract}

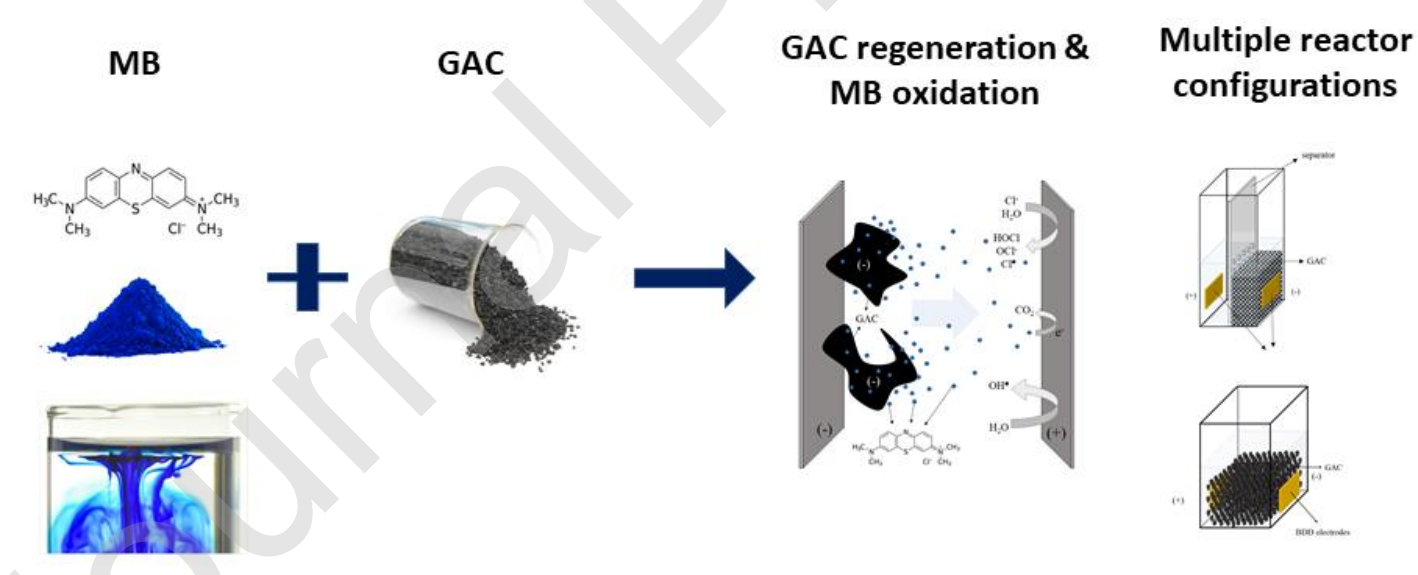

\section{Highlights}

- We report the electrolytic regeneration of GAC saturated with MBT on BDD as an anode.

- We compare three types of cell configuration, fluidized, packed bed (cathodic, anodic, and undivided). GAC packed in the cathodic compartment during the regeneration results in the highest RE. 
- Different regeneration cycles were carried out to evaluate its effect on the material, after three cycles of regeneration, the GAC lost $77 \%$ of its original surface area and $76 \%$ of its original adsorption capacity.

\begin{abstract}
The performance of an electrochemical process for the regeneration of granular activated carbon (GAC) was evaluated using boron-doped diamond (BDD) anodes. Three different configurations were tested in the reactor: fluidized bed, packed bed with a divided cell and packed bed with an undivided cell. The GAC used was previously saturated with a synthetic solution of methylene blue (MB). The effects of three operational parameters were evaluated: current density, initial $\mathrm{pH}$ and reaction time, and $\mathrm{NaCl}$ as the electrolyte. Regeneration efficiencies (REs) of up to $76 \% \pm 2$ were achieved with a current density of $6 \mathrm{~mA} \cdot \mathrm{cm}^{-2} \mathrm{during} 24$ $\mathrm{h}$ of reaction, and a specific electric energy consumption of $1530 \mathrm{kWh}$ ton $^{-1}$ of GAC was obtained. The best results were obtained using the packed bed reactor with a divided cell and the GAC in the cathodic compartment. The present results were attributed to an improvement in the desorption caused by the local alkaline $\mathrm{pH}$ in the cathodic compartment, to the contribution of the electrochemical oxidation by the hydroxyl radical, and, in parallel, to the chemical oxidation of the organic compounds by the oxidizing species formed from the chloride ion. It was also found that the electrochemical regeneration process has a negative effect on the GAC integrity after three cycles of continuous regeneration.
\end{abstract}

\title{
Keywords
}

BDD, Adsorption, electrolytic regeneration, wastewater.

\section{INTRODUCTION}

Granular activated carbon (GAC) can be considered a universal adsorbent due to its high adsorption capacity and low retention selectivity, which make it indispensable to a multitude of processes and applications. For this reason, the production and consumption of this adsorbent material have recently experienced a large increase [1]. However, the main problem with this technology is the implied cost for the final disposal of the material since 
the GAC retains the removed pollutants on its surface [2-5]; due to this characteristic, the feasibility and sustainability of GAC adsorption technology depends to a large extent on GAC reactivation and reutilization.

Several methods are currently used to regenerate GAC saturated with organic pollutants. The most used approach is thermal regeneration under an inert atmosphere or oxidizing conditions; this approach is characterized by a high energy consumption, high costs associated with the transportation of material to the regeneration center, material losses by oxidation and volatilization and the release of polluting gases during the reactivation process, in addition to the generation of chemical, physical and textural changes to the properties of the regenerated activated carbon [6,7]. Consequently, new techniques for regenerating GAC are being studied including wet air oxidation [8], ultrasonic treatment [9], microwave [10,11], ultraviolet irradiation [12], bio-regeneration [13], supercritical water or carbon dioxide regeneration $[14,15]$, chemical regeneration [16] and electrochemical treatments [17]. The latter is a novel technique that allows the regeneration of saturated GAC with a simultaneous in situ degradation at room temperature and pressure.

The GAC electrochemical regeneration (ER) consists of the desorption of the pollutants from the GAC surface with the application of a potential difference and the subsequent electrochemical oxidation degradation [18]. Studies show that the GAC ERs attain regeneration efficiencies (REs) of 70-100\%, with process times between 1.5 and $12 \mathrm{~h}$ [1922]. Weng and Hsu [22] evaluated the regeneration of a GAC used for landfill leachate treatment with graphite electrodes and obtained an RE of $91 \%$ in $24 \mathrm{~h}$ of process, with a 0.1 $\mathrm{M} \mathrm{NaCl}$ solution and a potential of $5 \mathrm{~V}$.

On the other hand, the oxidation of the pollutants is directly related to the nature of the electrode's material [23]. Boron-doped diamond (BDD) is the most recommended material 
for the electrochemical oxidation of organic compounds because it is a "nonactive" electrode and has a high oxygen evolution potential (2.2-2.6 V vs SHE); these properties favor the production of hydroxyl radicals and the subsequent oxidation of the organic matter close to the anode's surface $[23,24]$.

Two types of oxidations occur during the process, direct oxidation, caused by electron transfer between the organic matter and the anode's surface, and indirect oxidation, caused by the hydroxyl radicals generated in the electrolytic decomposition of $\mathrm{H}_{2} \mathrm{O}$ molecules (Eq. 1), as intermediates of the oxygen evolution (Eq. 3). These radicals are capable of nonselectively oxidizing organic matter up to its mineralization (Eq. 2). The indirect oxidation also occurs by the electrogeneration of oxidants on the electrode's surface, and this electrogeneration depends on the nature of the electrolyte that is used; for example, when using $\mathrm{NaCl}$, various strong oxidant species can be produced [25], such as hypochlorous acid (in acidic and neutral media), hypochlorite ions (in basic media) and chlorine gas (in acidic media), which attack the organic matter (Eqs. 4-7) [18,26].

$$
\begin{aligned}
& B D D+\mathrm{H}_{2} \mathrm{O} \rightarrow \mathrm{BDD}(\bullet \mathrm{OH})+\mathrm{H}^{+}+e^{-} \quad(\mathrm{E}=2.2-2.6 \mathrm{~V} \text { vs } \mathrm{SHE}) \\
& R+B D D(\bullet \mathrm{OH}) \rightarrow B D D+\mathrm{CO}_{2}+\mathrm{H}_{2} \mathrm{O}
\end{aligned}
$$

Although studies related to electrochemical regeneration have shown high efficiencies[1822], different types of reactors and configurations have been used in each of these, which 
have not been evaluated on the same basis, making it difficult to compare the regeneration efficiencies obtained [27]. For a better understanding of the process it is necessary to evaluate different operational variables. One of these variables is the configuration of the reactor, since the disposition of the GAC can affect the regeneration efficiency due to the localized electrochemical processes that can occur in the cell.

In this context, the main goal of the present study was to evaluate the effects of the current density, initial $\mathrm{pH}$ and operation time on the performance of the ER of GAC saturated with methylene blue (MB). MB was used as a model substance for the purpose of comparison with the electrochemical degradation results of previous studies [28-33], in fluidized bed and packed bed configurations, using BDD electrodes.

\section{MATERIALS AND METHODS}

\subsection{GAC preparation and MB adsorption}

Analytical grade MB trihydrate of the Allied Chemical Corporation brand was used for the adsorption. Commercial GAC, brand Calgon reference Filtrasorb® 400, was used with the

physical properties described in Table 1. The high surface area (SA) of $862 \mathrm{~m}^{2} \cdot \mathrm{g}^{-1}$ is highlighted and is the reason why the material is often used for the removal of organic compounds dissolved in effluents and wastewaters.

Table 1. Characterization of the GAC used.

GAC type

Abrasion number, min*

Apparent density, $\min \left(\mathrm{g} \cdot \mathrm{cm}^{-3}\right)^{*}$
Filtrasorb® 400

0.54 
Ash content (\%), max*

Particle diameter, $\mathrm{mm}^{*}$

$\mathrm{SA}, \mathrm{m}^{2} \cdot \mathrm{g}^{-1}$
5

$0.55-0.75$

862

* From Calgon. Carbon data sheet.

The MB concentration was measured in solution by the absorbance at $664 \mathrm{~nm}$ with a Spectroquant Merk Pharo 300 UV-VIS spectrophotometer. Additional absorbance spectra were performed between 300 and $750 \mathrm{~nm}$ with the same spectrophotometer to evaluate the pollutant's degradation. The $\mathrm{pH}$ measurements were performed with an Accumet Fischer $\mathrm{pH}$ meter.

The adsorption was studied through an isotherm to determine the maximum MB load that could be adsorbed by the GAC. Six different initial MB concentrations were used for the points of the isotherm: $75,225,375,450,475$ and $600 \mathrm{mg} \cdot \mathrm{L}^{-1}$, during $480 \mathrm{~h}$ at a stirring speed of $250 \mathrm{rpm}$ in a $100 \mathrm{~mL}$ Erlenmeyer loaded with $0.1 \mathrm{~g}$ of GAC. The equilibrium time was experimentally determined by taking a sample of the adsorption process every $4 \mathrm{~h}$ during the first $12 \mathrm{~h}$, and then, a sample was collected daily until there was no appreciable change in the $\mathrm{MB}$ in solution. Once the adsorption process was finalized, the solution was passed through a $0.45 \mu \mathrm{m}$ cellulose nitrate filter. The concentration of MB in the solution was measured as described above, and the concentration of $\mathrm{MB}$ in the GAC was determined by mass balance. This procedure was carried out in duplicate.

The Langmuir isotherm model was used for the analysis of the obtained data; this model is frequently used for the adsorption of a solute from a liquid solution [34]. Based on the standard equation (Eq. 8), different linearizations can be performed; the Weber linearization (Eq. 9) [35] was used for this study. 
$q_{e}=\frac{C_{e} b Q_{0}}{1+b C_{e}}$

Eq. 8

$\frac{C_{e}}{q_{e}}=\frac{1}{b Q_{0}}+\left(\frac{1}{Q_{0}}\right) C_{e}$

Where $\mathrm{q}_{\mathrm{e}}$ is the concentration of the solute retained on the adsorbent at a point $\left(\mathrm{mg} \mathrm{g}^{-1}\right), \mathrm{C}_{\mathrm{e}}$ is the concentration of solute in solution at a point $\left(\mathrm{mg} \cdot \mathrm{L}^{-1}\right)$, and $\mathrm{Q}_{\mathrm{o}}$ and $\mathrm{b}$ are the Langmuir parameters related to the maximum adsorption capacity and the adsorption binding energy, respectively.

For the initial GAC adsorption and the adsorption tests after the treatment, solutions of 1400 $\mathrm{mg} \cdot \mathrm{L}^{-1}$ of $\mathrm{MB}$ were used. The RE in each of the tests was calculated according to Eq. 10 .

$\mathrm{RE}=\frac{\text { Adsorption capacity of } M B T \text { on } G A C \text { after treatment }}{\text { Adsortption capacity of the virgin } G A C} * 100$

Eq. 10

Where the adsorption capacity of MB on GAC after treatment refers to the amount of MB that the GAC is capable of adsorbing after one ER cycle, and the adsorption capacity of the virgin GAC refers to the parameter $\mathrm{Q}_{0}$ from Langmuir isotherm (Eq. 9). This procedure was carried out in duplicate and the uncertainty was calculated with a significant level of 0.05 .

\subsection{Electrochemical characterization}

Cyclic voltammetry studies were performed, since upon application of an electric current, both desorption and electrochemical oxidation processes of the adsorbed contaminant is observed [36]. In the cyclic voltammetry tests a planar BDD electrode supported on a Si substrate manufactured by Fraunhofer-CCD, with a circular geometry $0.78 \mathrm{~cm}^{2}$ in area, was used in a conventional three-electrode arrangement [37]. A platinum wire with an area of 
$3.14 \mathrm{~cm}^{2}$ was used as the counter electrode, and $\mathrm{Ag} /(\mathrm{AgCl} / \mathrm{KCl}$ saturated $)$ as the reference electrode; a Gamry G750 series potentiostat/galvanostat was used for the measurements. The scanning rate was of $50 \mathrm{mV} \cdot \mathrm{s}^{-1}$ in a potential range from -1000 to $1500 \mathrm{mV}$. The electrolytic solution had $0.001 \mathrm{M} \mathrm{NaCl}$ and $50 \mathrm{mg} \cdot \mathrm{L}^{-1}$ of $\mathrm{MB}$.

\subsection{Electrochemical regeneration cell}

An acrylic cell (Figure 1) with an effective volume of $10 \mathrm{~cm}^{3}$ was used with two BDD electrodes supported on a $\mathrm{Si}$ substrate manufactured by Fraunhofer-CCD, both with geometric areas of $2.78 \mathrm{~cm}^{2}$. The cell was operated in four configurations: fluidized, anodic, cathodic and mixed, which depended on the position of the GAC inside the reactor compartments and on the amount of GAC; $0.4 \mathrm{~g}$ of GAC were used in the mixed, cathodic and anodic configurations. In the mixed configuration, the GAC was between the anode and the cathode without a separator. In the cathodic and anodic configurations (Figure 1a), the GAC was in direct contact with the cathode or anode, respectively, and separated from the rest of the cell with a polytetrafluoroethylene (PTFE) separator (pores $<500 \mu \mathrm{m}$ ), which allowed permeability of the solution to both compartments. In the fluidized configuration (Figure 1b), the bed was composed of $0.4 \mathrm{~g}$ of GAC, but was not in constant contact with 
either of the two electrodes.

(a)

$(+)$ (b)

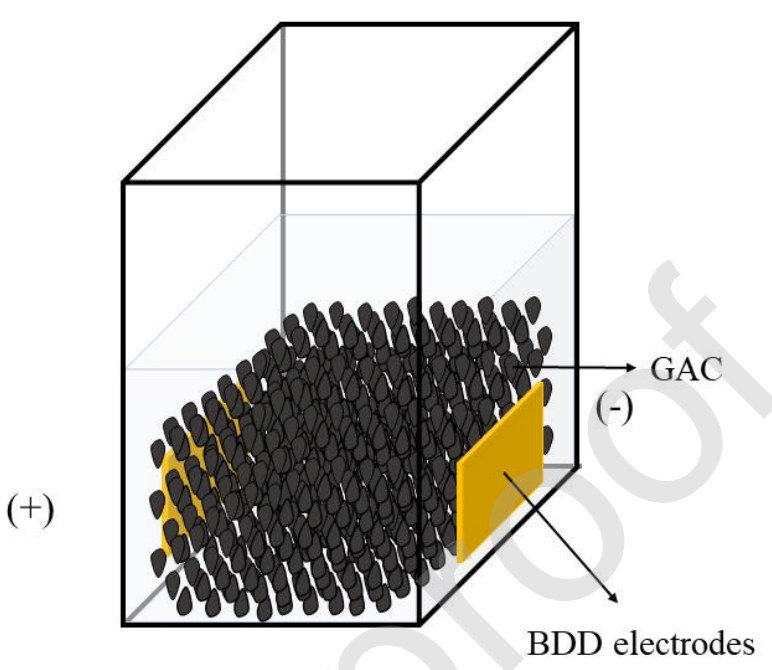

Figure 1. Schematic diagram of the (a) divided-cell reactor, packed bed configuration and

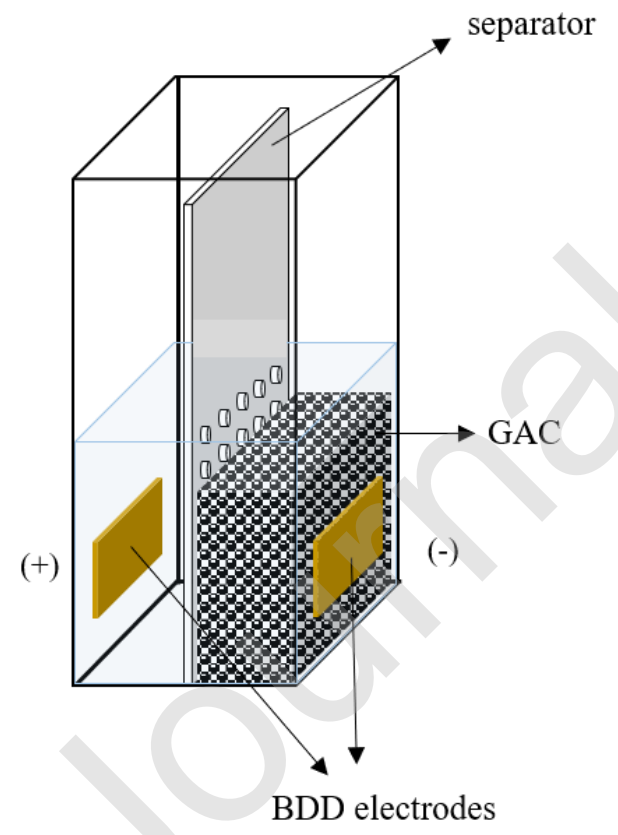

(b) undivided-cell reactor.

\subsection{Electrochemical regeneration tests}


The following variables were studied in the GAC regeneration tests: reactor configuration, current density, time and initial $\mathrm{pH}$, with the values presented in Table 2 .

Table 2. Variables for the performed experiments.

\begin{tabular}{ccccc}
\hline Bed type & $\begin{array}{c}\text { Regeneration } \\
\text { type }\end{array}$ & $\begin{array}{c}\text { Current density } \\
\left(\mathbf{m A} \cdot \mathbf{c m}^{-\mathbf{2}}\right)\end{array}$ & Time (h) & Initial pH \\
\hline Fluidized & mixed & 2,4 and 6 & 1 and 3 & 4,7 and 9 \\
Packed & $\begin{array}{c}\text { anodic, cathodic, } \\
\text { mixed }\end{array}$ & 2,4 and 6 & 1,3 and 24 & 7 \\
\hline
\end{tabular}

All tests were performed at $25 \pm 2{ }^{\circ} \mathrm{C}$ and atmospheric pressure in Santiago de Cali, Colombia ( 0.996 atm), and $10 \mathrm{~cm}^{3}$ of a $0.1 \mathrm{M} \mathrm{NaCl}$ solution, with an initial $\mathrm{pH}$ of 7 , was used for each test. The $\mathrm{pH}$ of the solutions was regulated with $\mathrm{H}_{2} \mathrm{SO}_{4}$ and $\mathrm{NaOH}$. This procedure was carried out in duplicate and the uncertainty was calculated with a significant level of 0.05 .

\subsubsection{Regeneration cycles}

An additional test was performed with three adsorption-regeneration-adsorption cycles using a unique GAC sample at $6 \mathrm{~mA} \cdot \mathrm{cm}^{-2}$ for $24 \mathrm{~h}$. A new $0.1 \mathrm{M} \mathrm{NaCl}$ solution with an initial $\mathrm{pH}$ of 7 was used for each test. For each regeneration cycle, the nonpurgeable organic carbon (NPOC) concentration in the residual solution was measured with the SHIMADZU total organic carbon analyzer TOC-V. Scanning electron microscopy (SEM) and BrunauerEmmett-Teller (BET) examinations were performed on the GAC, which was subjected to the same saturation conditions described in section 2.1, to obtain its new adsorption capacity. 


\subsection{Energy consumption}

The specific energy consumption $(\mathrm{Q})$ was calculated according to the following equation:

$Q=\frac{V * I * t}{1000 * w}$

Eq. 11

where $\mathrm{V}$ is the average voltage of the cell $(\mathrm{V}), \mathrm{I}$ is the current $(\mathrm{A}), \mathrm{t}$ is the electrolysis time $(\mathrm{s})$, and $\mathrm{w}$ is the GAC weight in tons $(\mathrm{t})$.

\section{RESULTS AND DISCUSSION}

\subsection{Adsorption isotherms}

Summarized in Table 3 are the constants and correlation coefficients of the Langmuir model calculated from the linearized equation of the isotherm in Figure 2.

Table 3. Parameters obtained from the Langmuir isotherm by linear regression.

\begin{tabular}{cccc}
\hline $\mathbf{Q}_{\mathbf{0}}\left[\mathbf{m g ~ g}^{-\mathbf{1}}\right]$ & $\mathbf{b}\left[\mathbf{L ~ \mathbf { ~ m g } ^ { - 1 } ]}\right.$ & $\mathbf{R}^{\mathbf{2}}$ & $\mathbf{R}_{\mathbf{L}}$ \\
\hline 371.75 & 0.747 & 0.9996 & $0.0020-0.019$ \\
\hline
\end{tabular}




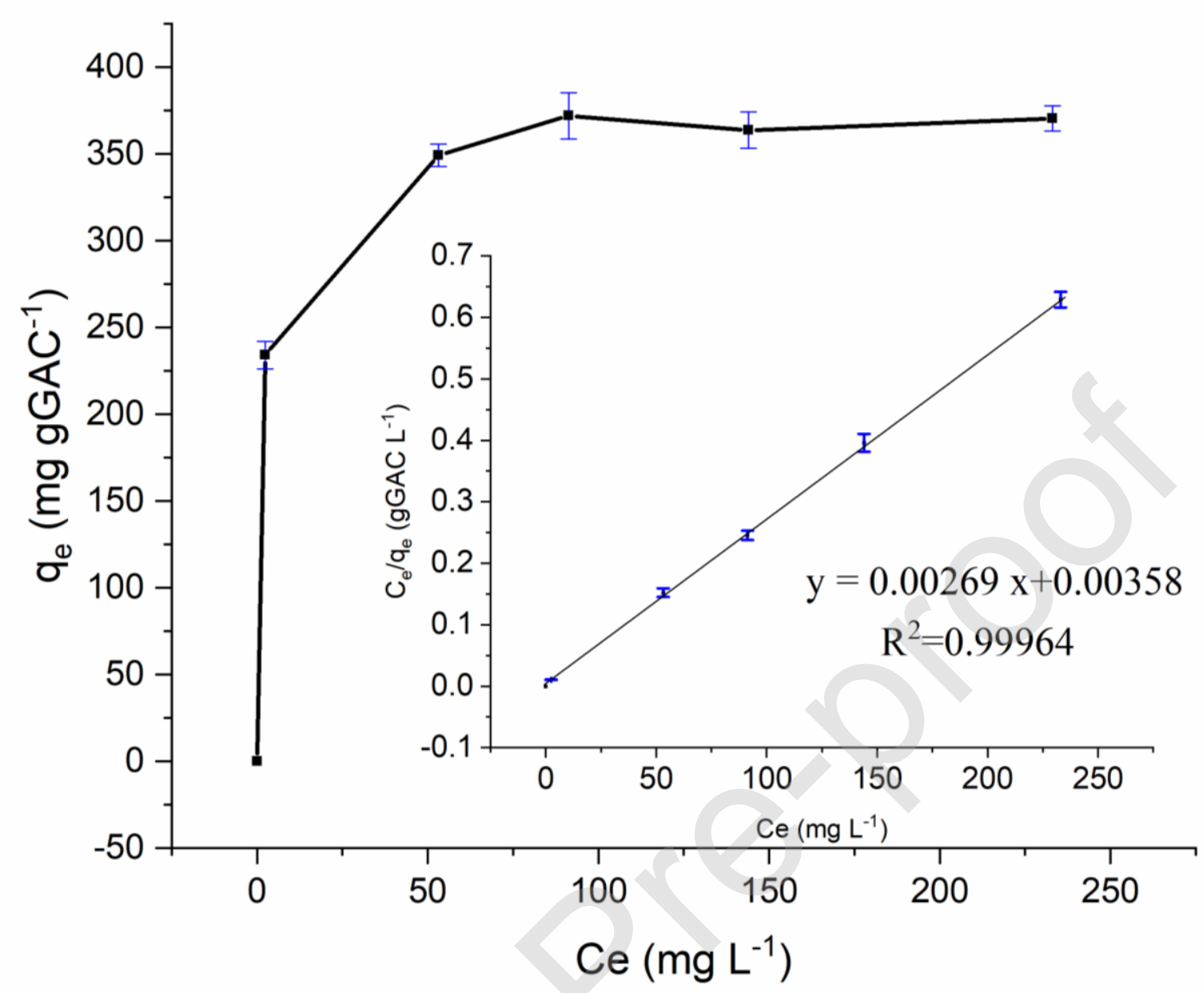

Figure 2. Langmuir isotherm of the Calgon Filtrasorb ${ }^{\circledR} 400$ activated carbon $\left(\mathrm{T}=25^{\circ} \mathrm{C}\right)$.

The experimental data for the isotherm were fitted to the Langmuir model with $\mathrm{R}^{2}=0.9996$. In addition, a maximum adsorption capacity $\left(\mathrm{Q}_{0}\right)$ of $371.75 \mathrm{mg} \mathrm{MB} \mathrm{gGAC}^{-1}$ was established in an equilibrium time of $480 \mathrm{~h}$; this value was used as the adsorption capacity of the virgin GAC for the calculation of the RE. Furthermore, in this study, the dimensionless equilibrium parameter $\mathrm{R}_{\mathrm{L}}\left(1 / 1+\mathrm{bC}_{0}\right)$ had values between 0.002 and 0.019 , which reaffirmed that the adsorption of MB on the GAC was favored.

Although these results are not directly comparable with those of previous studies because the conditions of the isotherms vary, a maximum adsorption of $219 \mathrm{mg} \mathrm{MB} \mathrm{gGAC}^{-1}$ was 
previously obtained with a Filtrasorb 100 carbon from Calgon Carbon [38]. Other commercial GACs, made from coconut shell and mineral carbon, show adsorption capacities between 289 and $309 \mathrm{mg} \mathrm{MB} \mathrm{gGAC}^{-1}$, under the conditions: a $\mathrm{pH}$ of 5 , a temperature of 25 ${ }^{\circ} \mathrm{C}$ and a time of $400 \mathrm{~h}[38]$.

\subsection{Electro-analytical study}

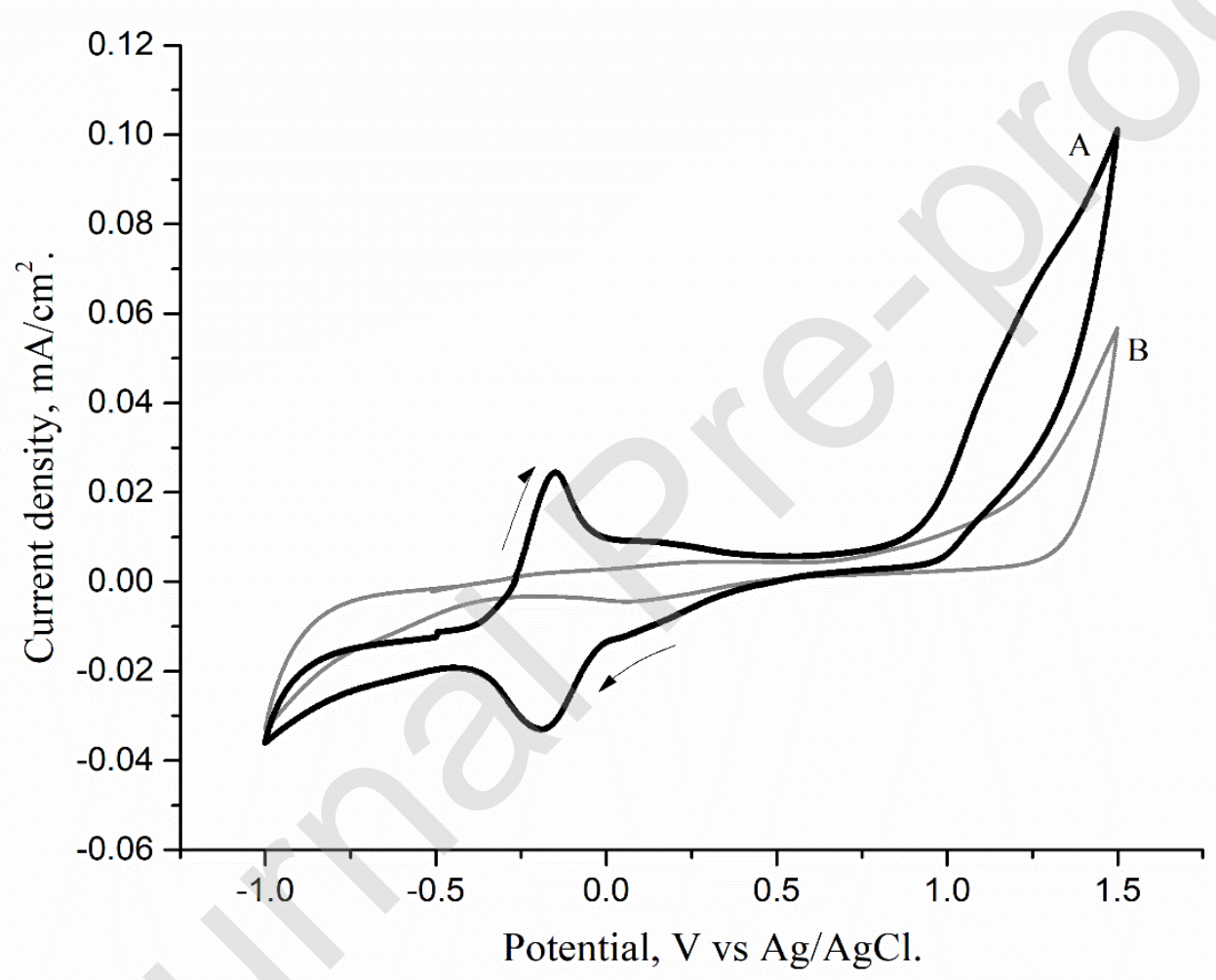

Figure 3. Cyclic voltammograms of solutions containing: A) $50 \mathrm{mg} \cdot \mathrm{L}^{-1}$ of $\mathrm{MB}$ and $0.001 \mathrm{M}$ of $\mathrm{NaCl}$ and $\mathrm{B}$ ) $0.001 \mathrm{M}$ of $\mathrm{NaCl}$ without $\mathrm{MB}$. Scan rate of $50 \mathrm{mV} \cdot \mathrm{s}^{-1}$.

Shown in Figure 3 is a cyclic voltammogram of a solution that contained $50 \mathrm{ppm}$ of MB in $0.001 \mathrm{M} \mathrm{NaCl}$ obtained using a BDD electrode. In the anodic scan, an oxidation peak appeared at $-140 \mathrm{mV}$, and under cathodic currents, a reduction peak appeared at 
approximately $-200 \mathrm{mV}$; both features were attributed to the pseudoreversible redox reaction of MB [37]. At higher potentials, an increase in the anodic current density was observed from 1000 to $1500 \mathrm{mV}$. A study attributes this phenomenon to the nonreversible electropolymerization of MB on the electrode's surface [37]. Finally, an exponential increase in the current density was observed at positive potentials above $1200 \mathrm{mV}$; this behavior is characteristic of the oxygen evolution reaction.

According to the above results and to mineralize the MB dissolved in solution, the decision was made to apply working current densities where the oxygen evolution reaction takes place (Anodic $\mathrm{E}>1.5 \mathrm{~V}$ vs Ag/AgCl, $\mathrm{i}>0.1 \mathrm{~mA} \cdot \mathrm{cm}^{-2}$ ) because the oxidation of the organic matter is favored by the production of hydroxyl radicals at the BDD [24], avoiding the electrode fouling.

\subsection{Electrochemical regeneration: $\mathrm{pH}$ effect}

The effect of the initial $\mathrm{pH}$ on the performance was evaluated using the fluidized bed reactor configuration at a current density of $2 \mathrm{~mA} \cdot \mathrm{cm}^{-2}$. The variation in the RE was found to be approximately $1.5 \%$ for $\mathrm{pH}$ values of 4, 7 and 9, as shown in Figure 4. This result indicates that the initial $\mathrm{pH}$ did not have a significant influence on the RE of the fluidized bed reactor. 


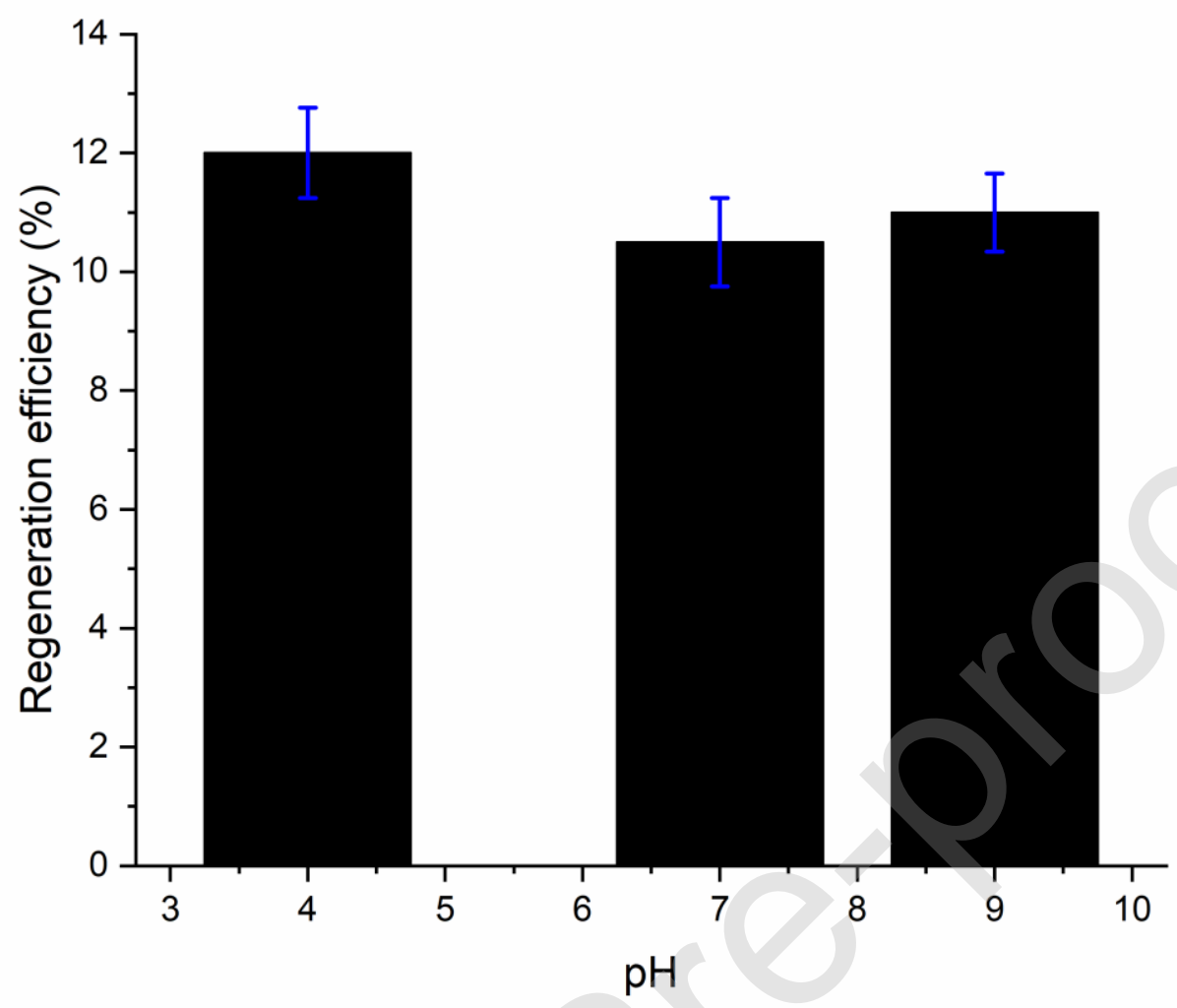

Figure 4. Effect of the initial $\mathrm{pH}$ on the RE. ER conditions: a current density of $2 \mathrm{~mA} \cdot \mathrm{cm}^{-2}$, $0.1 \mathrm{M} \mathrm{NaCl}, \mathrm{T}=25^{\circ} \mathrm{C}, 0.4 \mathrm{~g}$ of $\mathrm{GAC}$, and a contact time of $3 \mathrm{~h}$. Fluidized bed reactor.

Changes in the solution $\mathrm{pH}$ were observed during the process, as shown in Table 4 . For the packed bed reactor with cathodic regeneration, the $\mathrm{pH}$ of the medium decreased, whereas it increased for the anodic regeneration. This behavior can be explained by the GAC acting as an electrode that undergoes nonfaradic reactions on its high SA, such as the charging of the electrical double layer, and this phenomenon consume electrons that could have been used for the production of $\mathrm{OH}^{-}$ions in the hydrogen evolution reaction (cathodic regeneration) or for the production of $\mathrm{H}^{+}$ions (anodic regeneration). In addition, the $\mathrm{OH}^{-}$and $\mathrm{H}^{+}$ions can be adsorbed on the GAC [36]. This mechanism causes a $\mathrm{pH}$ increase or decrease since the 
reaction of the electrode that is not in contact with the GAC keeps generating $\mathrm{H}^{+}$(anode) or $\mathrm{OH}^{-}$(cathode) ions.

Table 4. Evolution of $\mathrm{pH}$ in the ER process.

\begin{tabular}{lcccc}
\hline & Fluidized & Mixed & Cathodic & Anodic \\
\hline Initial pH & $7.2 \pm 0.1$ & $7.2 \pm 0.1$ & $7.3 \pm 0.1$ & $7.3 \pm 0.1$ \\
Final pH & $9.9 \pm 0.1$ & $11.0 \pm 0.1$ & $2.8 \pm 0.1$ & $11.2 \pm 0.1$ \\
\hline
\end{tabular}

Additional tests were performed without applying electric energy to the process, to verify the desorption effect at different values of $\mathrm{pH}(4,7$ and 9). It was found that $\mathrm{RE}$ values of 4, 6 and $4 \%$, were obtained respectively. The above data indicate the important effect of the electrochemical process for the GAC regeneration and that the desorption due to the $\mathrm{pH}$ solution (4, 7 and 9$)$ is negligible.

\subsection{Electrochemical regeneration: Effect of reactor configuration}

In the fluidized bed reactor configuration, REs below $20 \%$ were obtained (Figure 5); this result is attributed to the particular configuration that does not allow the direct contact of all the porous material with the electrodes causing not uniform polarization of the particles, which has a negative impact on the pollutant desorption. On the other hand, in the packed bed configuration, the best $\operatorname{RE}(55 \% \pm 2)$ was obtained at $3 \mathrm{~h}$ and $6 \mathrm{~mA} \cdot \mathrm{cm}^{-2}$, which is between $3 \%$ to $9 \%$ higher than the regenerations attained when the GAC was in contact with the anode and with both electrodes (mixed). This result is consistent with the investigation performed by Narbaitz et al [39], where the cathodic regeneration is $5-10 \%$ more efficient than the 
anodic regeneration.

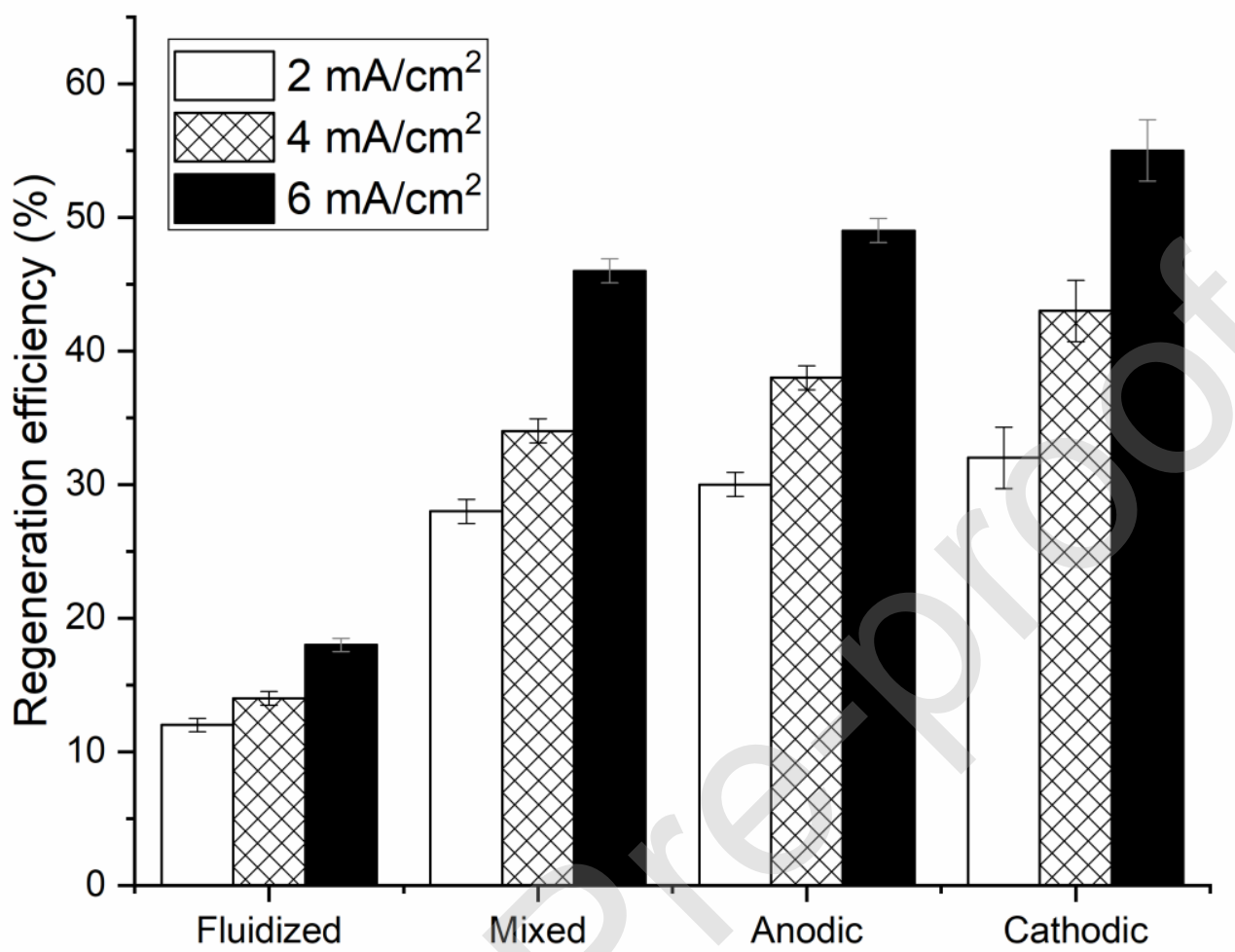

Figure 5. Effect of the type of ER on the RE. ER conditions: current densities of 2, 4 and 6 $\mathrm{mA} \cdot \mathrm{cm}^{-2}, 0.1 \mathrm{M} \mathrm{NaCl}, \mathrm{T}=25^{\circ} \mathrm{C}, 0.4 \mathrm{~g}$ of GAC, and a contact time of $3 \mathrm{~h}$.

The good efficiency of the cathodic compartment, compared with that of the anodic compartment, can be due to the change in the local $\mathrm{pH}$ at the GAC, due to the hydroxyl ions $\left(\mathrm{OH}^{-}\right)$generated at the GAC when polarized as cathode; this change in local $\mathrm{pH}$ can be sufficient to shift the adsorbate-adsorbent adsorption equilibrium and promote the desorption processes [40]. It is also known that the competitive adsorption with hydroxyl ions and the increase in solubility of the organic compounds with the $\mathrm{pH}$ stimulate the desorption processes. In contrast, acidic environments decrease the solubility of the organic compounds and neutralize the functional groups on the GAC surface [41]. 
In addition to the desorption, the oxidation of the MB molecule occurs as a consequence of the hydroxyl radicals generated at the BDD anode's surface (Eq. 1). The activity of the hydroxyl ions is strongly linked to their interaction with the electrode's surface; however, for the case of the BDD, this radical-surface interaction is very weak so that the $\bullet O H$ can be considered as free, which allows the oxidation of the other compounds in the vicinity of the anode's surface [23]. The presence of chlorine in the electrolytic reactor gives rise to the electrogeneration of oxidizing species (hypochlorite ions, hypochlorous acid, chloride ions or chlorine gas, depending on the $\mathrm{pH}$ ), which contribute to the mineralization of the $\mathrm{MB}$, as illustrated in Eqs. 4-7 [18,26,42].

\subsection{Electrochemical regeneration: Effect of current density and regeneration time}

The results show that the RE is proportional to the time and the current density used (Table 5). The highest efficiency values were obtained for a current density of $6 \mathrm{~mA} \cdot \mathrm{cm}^{-2}$; at higher current densities, the phenomena resulting from the polarization of the electrodes and the GAC are accelerated, such as the amounts of $\bullet O H$ radicals and intermediate species (Eqs. 18). This action increases the oxidation as well as the production of $\mathrm{OH}^{-}$ions in the case of the cathodic configuration, which in turn increases the local $\mathrm{pH}$ and favors desorption $[2,30,43,44]$. These results are consistent with other studies on GAC electrochemical regeneration, which suggest that longer regeneration time results in a higher RE [45].

The results obtained for 1 and $3 \mathrm{~h}$ were in the range of $26-55 \% \pm 1 \mathrm{RE}$ (Table 5). These results are unattractive for a GAC regeneration process. Due to these results, ER tests were performed at current densities of 2 and $6 \mathrm{~mA} \cdot \mathrm{cm}^{-2}$ for an operation time of $24 \mathrm{~h}$ (Table 5). 
Consequently, an RE increase of $76 \% \pm 2$ was observed in the cathodic configuration, which is a $21 \%$ increase with respect to the previous results.

Table 5. RE at different conditions of current density and time.

\begin{tabular}{ccccccccccc}
\hline & \multicolumn{3}{c}{ Mixed } & \multicolumn{3}{c}{ Anodic } & \multicolumn{3}{c}{ Cathodic } \\
$\mathbf{J}\left(\mathbf{m A} \cdot \mathbf{c m}^{-2}\right)$ & $\mathbf{1 ~ h}$ & $\mathbf{3 ~ h}$ & $\mathbf{2 4} \mathbf{h}$ & $\mathbf{1 ~ h}$ & $\mathbf{3 ~ h}$ & $\mathbf{2 4} \mathbf{~ h}$ & $\mathbf{1 ~ h}$ & $\mathbf{3 ~ h}$ & $\mathbf{2 4} \mathbf{~ h}$ \\
\hline $\mathbf{0}$ & - & $6 \pm 1$ & - & - & $6 \pm 1$ & - & - & $6 \pm 2$ & - \\
$\mathbf{2}$ & $26 \pm 1$ & $28 \pm 1$ & $58 \pm 1$ & $27 \pm 1$ & $30 \pm 1$ & $62 \pm 1$ & $29 \pm 2$ & $32 \pm 2$ & $65 \pm 2$ \\
$\mathbf{4}$ & $28 \pm 1$ & $34 \pm 1$ & - & $30 \pm 1$ & $38 \pm 1$ & - & $32 \pm 2$ & $43 \pm 2$ & - \\
$\mathbf{6}$ & $32 \pm 1$ & $46 \pm 1$ & $68 \pm 1$ & $33 \pm 1$ & $49 \pm 1$ & $71 \pm 1$ & $35 \pm 2$ & $55 \pm 2$ & $76 \pm 2$ \\
\hline
\end{tabular}

\subsection{Electrochemical regeneration: Effect of regeneration cycles}

The amount of organic compounds, NPOC, dissolved in the electrolyte at the end of three regeneration cycles (table 6) at a current density of $6 \mathrm{~mA} \cdot \mathrm{cm}^{-2}$ for $24 \mathrm{~h}$, was $98 \%$ lower in comparison with the initial amount of MB adsorbed on the GAC. This result is attributed to the oxidation processes that mineralize most of the desorbed organic matter $[18,21,46,47]$. This confirms that the process is governed by a mechanism that includes both the desorption and the oxidation; however the accumulation of the recalcitrant intermediates of the MB and of the organic substances remaining inside the GAC from the previous cycles are evidenced by the increase in the NPOC of the electrolyte after the third cycle in comparison with the first cycle. 
Table 6. Regeneration cycles.

\begin{tabular}{lcccc}
\hline Stage & $\begin{array}{c}\text { Final NPOC } \\
\left(\mathbf{m g ~ d m}^{-3}\right)\end{array}$ & $\begin{array}{c}\text { \% NPOC } \\
\text { removal * }\end{array}$ & SA $\left(\mathbf{m}^{2} \cdot \mathbf{g}^{-1}\right)$ & \% Regeneration \\
\hline First cycle & 11 & 99 & 431.25 & 76 \\
Third cycle & 16 & 98 & 194.64 & 24 \\
\hline
\end{tabular}

* Final NPOC vs theoretical NPOC of the electrolyte, assuming that the MB desorption occurs in the same proportion as that of the GAC RE under the operation conditions (76\%), that is, a solution with a NPOC concentration of $813 \mathrm{mg} \mathrm{dm}^{-3}$.

The BET technique was used to evaluate the effect of the regeneration process on the SA after subsequent cycles. The SA value of the virgin GAC was $862 \mathrm{~m}^{2} \cdot \mathrm{g}^{-1}$; this result is within the expected range of SA values, considering that commercial GACs have a SA on the order of 800 to $1100 \mathrm{~m}^{2} \cdot \mathrm{g}^{-1}[31,48]$. Table 6 shows a decrease in the SA of $77 \%$ with respect to the virgin GAC and a RE of only $24 \%$ after the third regeneration cycle. This loss can be due to different factors, for example, the adsorption time of the MB was approximately $20 \mathrm{~d}$ to ensure saturation, and due to this long period of time, it is possible that the MB molecules reached the micropores having a negative impact on the RE since the GAC is easier to regenerate when the molecules are only adsorbed in the meso-and macropores [49]. Another possibilities can be, the effect of attrition generated by the motion of the activated carbon in the packed bed due to the bubbles weakening the structure of the GAC which provokes material losses and produces a plugging effect in the pores, that is, part of the carbon detaches from its structure and occupies empty spaces within it[50]; the destruction of the micropores fraction due to the oxidation of AC when charged with higher current densities [26], is also possible. To overcome this, more efficient configurations are being developed and evaluated in our ongoing research, to ensure a better confinement of the GAC and an efficient contact 
between the GAC and the current distributor (electrode).

Shown in Figure 6 are the SEM micrographs of the GAC surface morphology at 100x. In Figure 6(a), the irregular and porous surface of the virgin GAC is observed and is in accordance with the bituminous coal nature, which presents amorphous structures without defined patterns, in comparison with vegetable activated carbons. Shown in Figure 6(b) is the surface of the GAC saturated with organic matter, yielding a structure that is a slightly less irregular and with little porosity. Figure 6(c) shows the GAC surface after the ER treatment, and a more irregular structure and larger cracks are observed than those seen in the virgin GAC. Based on the images, the ER process has a negative effect on the GAC integrity; this effect can be attributed to the constant friction of the particles inside the electrochemical cell and the high potentials used, giving rise to a possible oxidation and attrition by $\mathrm{H}_{2}$ and $\mathrm{O}_{2}$ gas evolution in the GAC surface.
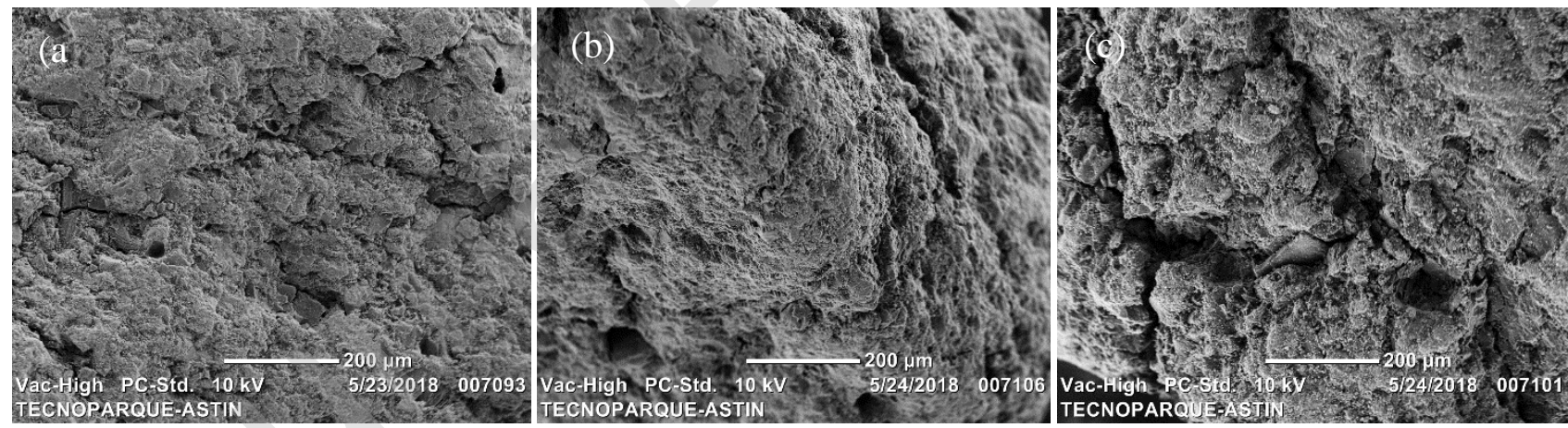

Figure 6. SEM images of (a) virgin GAC, (b) saturated GAC, and (c) regenerated GAC, first cycle.

To avoid this type of damage in the morphology of the GAC, actions the following actions should be taken: 1) reduce the thickness of the bed, thus reducing the pressure drop within the system, evading entrainment of material that may cause attrition effect in the process[51, 
52], 2) control the flow of the solution, to prevent friction inside the bed that cracks and damages the carbon [53] and 3) reduce the time of exposure of the carbon to the current to avoid oxidation of the material [36].

\subsection{Energy consumption}

Finally, the specific energy consumption per ton of GAC was evaluated using Eq. 11. For that, the average voltage of the tests at $6 \mathrm{~mA} \cdot \mathrm{cm}^{-2}$ for $24 \mathrm{~h}$ was considered and amounted to 5.4 V. A specific electric energy consumption of $1530 \mathrm{kWh}^{-1}$ of GAC was obtained as a result. When compared with the conventional thermal regeneration, where the consumption is approximately $1000 \mathrm{kWh}_{\text {ton }}^{-1}$ of GAC [54], or with microwave regeneration, where values on the order of $2380 \mathrm{kWh} \mathrm{ton}^{-1}$ of GAC [55] are obtained, the ER presents an intermediate energy consumption value.

However, it is important to highlight that the energy consumption higher than the thermal process, can be compensated for by the savings achieved from the transportation stage of the activated carbon because the electrochemical process allows the in situ GAC regeneration, which greatly simplifies the process.

Additionally, though BDD is known for its high stability and no loss of electrode performance was perceived in this research, corrosion of BDD coated electrodes could still occur at an appreciable rate under high current density; to overcome this in future research the use of $\mathrm{Nb}$ substrate BDD electrodes, commercially available [56], is recommended because it possess a superior service life and major mechanical performance than Ti/BDD or Si/BDD. They also have been already on the market and applied in wastewater treatment applications [57]. 


\section{Conclusions}

The best GAC ER conditions are generated by a combined effect of the change in $\mathrm{pH}$ of the cathodic compartment, the electrochemical oxidation by the hydroxyl radicals of the organic compounds desorbed and the chemical oxidation product of the oxidizing species formed from the chloride ion.

The parameters that affect the efficiency of the ER process are the current density (j), regeneration time and cell configuration, with a maximum efficiency of $76 \%$ in $24 \mathrm{~h}$, at 6 $\mathrm{mA} \cdot \mathrm{cm}^{-2}$ and using cathodic regeneration with electrolytic support of $0.1 \mathrm{M} \mathrm{NaCl}$.

The type of electrochemical cell used, with fluidized bed or packed bed, has an important effect on the regeneration effectiveness, since efficiencies $20 \%$ higher were achieved under the same conditions when the packed bed configuration was used. This result is because the fluidized bed reactor does not allow for uniform contact between the porous material and the electrodes, preventing the desorption of the pollutant.

The ER process has a negative effect on the GAC integrity; this effect can be attributed to the constant friction of the particles inside the electrochemical cell and the high potentials used that my cause oxidation and attrition by $\mathrm{H}_{2}$ and $\mathrm{O}_{2}$ gas evolution in the GAC surface.

Credit author statement

All persons who meet authorship criteria are listed as authors, and all authors certify that they have participated sufficiently in the work to take public responsibility for the content, including participation in the concept, design, analysis, writing, or revision of the manuscript. Furthermore, each author certifies that this material or similar material has not been and will not be submitted to or published in any other publication before its appearance in the Journal of Environmental Chemical Engineering.

CRediT author statement, with individual contributions:

- Jawer Acuña-Bedoya: Formal Analysis, Investigation, Writing - Original Draft, Writing - Review \& Editing

- Jovannis A Comas-Cabrales: Methodology, Investigation, Writing - Review \& Editing, Visualization, Software 
- Christian E Alvarez-Pugliese: Conceptualization, Methodology, Validation, Writing - Review \& Editing, Data Curation

- Nilson Marriaga-Cabrales: Conceptualization, Methodology, Validation, Supervision, Project Administration, Funding Acquisition, Resources

\section{Declaration of interests}

The authors declare that they have no known competing financial interests or personal relationships that could have appeared to influence the work reported in this paper.

Conflict of Interest: The authors declare that they have no conflict of interest.

Funding: This study was funded by the Universidad del Valle.

\section{Acknowledgements}

The authors would like to thank Colciencias for funding the doctoral studies of Christian E. Alvarez-Pugliese and the Universidad del Valle for funding this research under grant "Bolsa Concursable 2017-Corte I: “REGENERACIÓN ELECTROQUÍMICA DE CARBÓN ACTIVADO GRANULAR CON ELECTRODOS DE DIAMANTE DOPADO CON BORO”.

\section{References}

[1] M.O. Omorogie, J.O. Babalola, E.I. Unuabonah, Regeneration strategies for spent solid matrices used in adsorption of organic pollutants from surface water: a critical review, Desalin. Water Treat. 57 (2016) 518-544. 
doi:10.1080/19443994.2014.967726.

[2] L. Wang, N. Balasubramanian, Electrochemical regeneration of granular activated carbon saturated with organic compounds, Chem. Eng. J. 155 (2009) 763-768. doi:10.1016/j.cej.2009.09.020.

[3] X. Liu, G. Yu, W. Han, Granular activated carbon adsorption and microwave regeneration for the treatment of 2,4,5-trichlorobiphenyl in simulated soil-washing solution, 147 (2007) 746-751. doi:10.1016/j.jhazmat.2007.01.076.

[4] X. Quan, X.L. Â, L. Bo, S. Chen, Y. Zhao, X. Cui, Regeneration of acid orange 7exhausted granular activated carbons with microwave irradiation, 38 (2004) 44844490. doi:10.1016/j.watres.2004.08.031.

[5] J.-L. Lim, M. Okada, Regeneration of granular activated carbon using ultrasound., Ultrason. Sonochem. 12 (2005) 277-282. doi:10.1016/j.ultsonch.2004.02.003.

[6] P.M. Alvarez, F.J. Beltran, V. Gomez-Serrano, J. Jaramillo, E.M. Rodriguez, Comparison between thermal and ozone regenerations of spent activated carbon exhausted with phenol, Water Res. 38 (2004) 2155-2165. doi:10.1016/j.watres.2004.01.030.

[7] R.M. Narbaitz, A. Karimi- Jashni, Electrochemical regeneration of granular activated carbons loaded with phenol and natural organic matter, Environ. Technol. 30 (2009) 27-36. doi:10.1080/09593330802422803.

[8] I. Benhamed, L. Barthe, R. Kessas, C. Julcour, H. Delmas, Effect of transition metal impregnation on oxidative regeneration of activated carbon by catalytic wet air oxidation, Appl. Catal. B Environ. 187 (2016) 228-237.

doi:10.1016/j.apcatb.2016.01.016.

[9] D. Feng, H. Tan, J.S.J. Van Deventer, Ultrasonic elution of gold from activated 
carbon, Miner. Eng. 16 (2003) 257-264.

[10] K.Y. Foo, B.H. Hameed, Microwave-assisted regeneration of activated carbon, Bioresour. Technol. 119 (2012) 41-47. doi:10.1016/j.biortech.2012.05.061.

[11] Q. Zhang, S. Cheng, H. Xia, L. Zhang, Removal of Congo red and methylene blue using $\mathrm{H} 2 \mathrm{O} 2$ modified activated carbon by microwave regeneration: isotherm and kinetic studies, Mater. Res. Express. 6 (2019) 0-22.

[12] Y. Sun, B. Zhang, T. Zheng, P. Wang, Regeneration of activated carbon saturated with chloramphenicol by microwave and ultraviolet irradiation, Chem. Eng. J. 320 (2017) 264-270. doi:10.1016/j.cej.2017.03.007.

[13] M. El Gamal, H.A. Mousa, M.H. El-Naas, R. Zacharia, S. Judd, Bio-regeneration of activated carbon: A comprehensive review, Sep. Purif. Technol. 197 (2018) 345359. doi:10.1016/j.seppur.2018.01.015.

[14] Y. Zhang, D. Yang, P. Ning, Y. Li, S. Tian, J. Gu, Regeneration of Phenol-Saturated Activated Carbon by Supercritical Water: Effect of $\mathrm{H} 2 \mathrm{O} 2$ and Alkali Metal Catalysts, J. Environ. Eng. (United States). 145 (2019) 1-10. doi:10.1061/(ASCE)EE.1943-7870.0001601.

[15] Y. Ito, I. Ushiki, Y. Sato, H. Inomata, Influence of Heat Treatment in Exhaust Treatment Process on Activated Carbon Regeneration using Supercritical Carbon Dioxide, KAGAKU KOGAKU RONBUNSHU. 45 (2019) 133-139. doi:10.1252/kakoronbunshu.45.133.

[16] Q. Li, Y. Qi, C. Gao, Chemical regeneration of spent powdered activated carbon used in decolorization of sodium salicylate for the pharmaceutical industry, J. Clean. Prod. 86 (2015) 424-431. doi:10.1016/j.jclepro.2014.08.008.

[17] R.M. Narbaitz, A. Karimi-Jashni, Electrochemical reactivation of granular activated 
carbon: Impact of reactor configuration, Chem. Eng. J. 197 (2012) 414-423. doi:10.1016/j.cej.2012.05.049.

[18] M. Zhou, L. Lei, The role of activated carbon on the removal of p-nitrophenol in an integrated three-phase electrochemical reactor, Chemosphere. 65 (2006) 1197-1203. doi:10.1016/j.chemosphere.2006.03.054.

[19] R. Berenguer, J.P. Marco-Lozar, C. Quijada, D. Cazorla-Amorós, E. Morallón, Electrochemical regeneration and porosity recovery of phenol-saturated granular activated carbon in an alkaline medium, Carbon N. Y. 48 (2010) 2734-2745. doi:10.1016/j.carbon.2010.03.071.

[20] M. Garcia-Oton, F. Montilla, M.A. Lillo-Rodenas, E. Morallón, J.L. Vazquez, Electrochemical Regeneration of Activated Carbon Saturated with Toluene, J. Appl. Electrochem. 35 (2005) 319-325. doi:10.1007/s10800-004-7470-3.

[21] H. Zhang, Regeneration of exhausted activated carbon by electrochemical method, 85 (2002) 81-85. doi:https://doi.org/10.1016/S1385-8947(01)00176-0.

[22] C.-H. Weng, M.-C. Hsu, Regeneration of granular activated carbon by an electrochemical process, Sep. Purif. Technol. 64 (2008) 227-236. doi:10.1016/j.seppur.2008.10.006.

[23] C. Comninellis, G. Chen, Electrochemistry for the Enviroment, New York, 2008. http://medcontent.metapress.com/index/A65RM03P4874243N.pdf (accessed March $12,2014)$.

[24] D. Gandini, E. Mahé, P.A. Michaud, W. Haenni, A. Perret, C. Comninellis, Oxidation of carboxylic acids at boron-doped diamond electrodes for wastewater treatment, J. Appl. Electrochem. 30 (2000) 1345-1350. doi:10.1023/A:1026526729357. 
[25] A.A. Najafpoor, M. Davoudi, E. Rahmanpour Salmani, Decolorization of synthetic textile wastewater using electrochemical cell divided by cellulosic separator, $\mathrm{J}$. Environ. Heal. Sci. Eng. 15 (2017) 1-11. doi:10.1186/s40201-017-0273-3.

[26] M.H. Zhou, L.C. Lei, Electrochemical regeneration of activated carbon loaded with p-nitrophenol in a fluidized electrochemical reactor, Electrochim. Acta. 51 (2006) 4489-4496. doi:10.1016/j.electacta.2005.12.028.

[27] R.M. Narbaitz, J. Cen, Alternative methods for determining the percentage regeneration of activated carbon, Water Res. 31 (1997) 2532-2542. doi:10.1016/S0043-1354(97)00085-7.

[28] T.C. An, X.H. Zhu, Y. Xiong, Feasibility study of photoelectrochemical degradation of methylene blue with three-dimensional electrode-photocatalytic reactor, Chemosphere. 46 (2002) 897-903. doi:10.1016/S0045-6535(01)00157-6.

[29] I. Bouaziz, M. Hamza, A. Sellami, R. Abdelhedi, A. Savall, K. Groenen Serrano, New hybrid process combining adsorption on sawdust and electroxidation using a BDD anode for the treatment of dilute wastewater, Sep. Purif. Technol. 175 (2017) 1-8. doi:10.1016/j.seppur.2016.11.020.

[30] C. a. Martínez-Huitle, E. Brillas, Decontamination of wastewaters containing synthetic organic dyes by electrochemical methods: A general review, Appl. Catal. B Environ. 87 (2009) 105-145. doi:10.1016/j.apcatb.2008.09.017.

[31] C. Zhang, Y. Jiang, Y. Li, Z. Hu, L. Zhou, M. Zhou, Three-dimensional electrochemical process for wastewater treatment: A general review, Chem. Eng. J. 228 (2013) 455-467. doi:10.1016/j.cej.2013.05.033 Review.

[32] P. Sathishkumar, R. Viswanathan, Review on the recent improvements in sonochemical and combined sonochemical oxidation processes - A powerful tool for 
destruction of environmental contaminants, Renew. Sustain. Energy Rev. 55 (2016) 426-454. doi:10.1016/j.rser.2015.10.139.

[33] Z. Ren, D. Zhou, L. Zhang, M. Yu, Z. Wang, Y. Fan, ZnSn ( OH ) 6 Photocatalyst for Methylene Blue Degradation : Electrolyte-Dependent Morphology and Performance, (2018) 10849-10856. doi:10.1002/slct.201802195.

[34] F. Raposo, M.A. De La Rubia, R. Borja, Methylene blue number as useful indicator to evaluate the adsorptive capacity of granular activated carbon in batch mode: Influence of adsorbate/adsorbent mass ratio and particle size, J. Hazard. Mater. 165 (2009) 291-299. doi:10.1016/j.jhazmat.2008.09.106.

[35] C.B. Beck, Physicochemical processes for water quality control, Wiley Interscience, John Wiley \& Sons, New York, 1973. doi:10.1002/aic.690190245.

[36] R. V. McQuillan, G.W. Stevens, K.A. Mumford, The electrochemical regeneration of granular activated carbons: A review, J. Hazard. Mater. 355 (2018) 34-49. doi:10.1016/j.jhazmat.2018.04.079.

[37] B. Liu, H. Cang, L. Cui, H. Zhang, Electrochemical polymerization of methylene blue on glassy carbon electrode, Int. J. Electrochem. Sci. 12 (2017) 9907-9913. doi:10.20964/2017.10.49.

[38] S. Wang, Z.H. Zhu, A. Coomes, F. Haghseresht, G.Q. Lu, The physical and surface chemical characteristics of activated carbons and the adsorption of methylene blue from wastewater, 284 (2005) 440-446. doi:10.1016/j.jcis.2004.10.050.

[39] R.M. Narbaitz, J. Cen, Electrochemical regeneration of granular activated carbon, Water Res. 28 (1994) 1771-1778. doi:10.1016/0043-1354(94)90250-X.

[40] A. Karimi-Jashni, R.M. Narbaitz, Electrochemical reactivation of granular activated carbon: pH dependence, J. Environ. Eng. Sci. 4 (2005) 187-194. doi:10.1139/s04- 
055.

[41] A. Karimi-Jashni, R.M. Narbaitz, Electrochemical Reactivation of Granular Activated Carbon: Effect of Electrolyte Mixing, J. Environ. Eng. 131 (2005) 443449. doi:10.1061/(ASCE)0733-9372(2005)131:3(443).

[42] C.E. Alvarez-Pugliese, J. Acuña-Bedoya, S. Vivas-Galarza, L.A. Prado-Arce, N. Marriaga-Cabrales, Electrolytic regeneration of granular activated carbon saturated with diclofenac using BDD anodes, Diam. Relat. Mater. 93 (2019) 193-199. doi:10.1016/j.diamond.2019.02.018.

[43] C.J. Sun, L.Z. Sun, X.X. Sun, Graphical evaluation of the favorability of adsorption processes by using conditional langmuir constant, Ind. Eng. Chem. Res. 52 (2013) 14251-14260. doi:10.1021/ie401571p.

[44] R. Xie, X. Meng, P. Sun, J. Niu, W. Jiang, Applied Catalysis B : Environmental Electrochemical oxidation of ofloxacin using a TiO 2 -based kinetics and mass transfer impact, "Applied Catal. B, Environ. 203 (2017) 515-525. doi:10.1016/j.apcatb.2016.10.057.

[45] W. Zhou, X. Meng, Y. Ding, L. Rajic, J. Gao, Y. Qin, A.N. Alshawabkeh, "Selfcleaning" electrochemical regeneration of dye-loaded activated carbon, Electrochem. Commun. 100 (2019) 85-89. doi:10.1016/j.elecom.2019.01.025.

[46] J. Zou, X. Peng, M. Li, Y. Xiong, B. Wang, F. Dong, B. Wang, Electrochemical oxidation of COD from real textile wastewaters: Kinetic study and energy consumption, Chemosphere. 171 (2017) 332-338. doi:10.1016/j.chemosphere.2016.12.065.

[47] J. Muff, H. Jepsen, E. Søgaard, Bench-Scale Study of Electrochemical Oxidation for On-Site Treatment of Polluted Groundwater, J. Environ. Eng. 138 (2012) 915-922. 
doi:10.1061/(ASCE)EE.1943-7870.0000561.

[48] P.J. Tauetsile, E.A. Oraby, J.J. Eksteen, Adsorption behaviour of copper and gold glycinates in alkaline media onto activated carbon. Part 1: Isotherms, Hydrometallurgy. 178 (2018) 202-208. doi:10.1016/j.hydromet.2018.04.015.

[49] B. Karabacakoğlu, O. Savlak, Electrochemical Regeneration of Cr (VI) Saturated Granular and Powder Activated Carbon : Comparison of Regeneration Efficiency, Ind. Eng. Chem. Res. 53 (2014). doi:dx.doi.org/10.1021/ie500161d.

[50] K.Y. Foo, B.H. Hameed, A short review of activated carbon assisted electrosorption process: An overview, current stage and future prospects, J. Hazard. Mater. 170 (2009) 552-559. doi:10.1016/j.jhazmat.2009.05.057.

[51] J.M.P.Q. Delgado, A critical review of dispersion in packed beds, Heat Mass Transf. Und Stoffuebertragung. 42 (2006) 279-310. doi:10.1007/s00231-005-0019-0.

[52] N. - W Han, J. Bhakta, R.G. Carbonell, Longitudinal and lateral dispersion in packed beds: Effect of column length and particle size distribution, AIChE J. 31 (1985) 277-288. doi:10.1002/aic.690310215.

[53] D. Nemec, J. Levec, Flow through packed bed reactors: 1. Single-phase flow, Chem. Eng. Sci. 60 (2005) 6947-6957. doi:10.1016/j.ces.2005.05.068.

[54] Mintek, Energy efficient Minfurn TM for regeneration of activated carbon, (n.d.) 1. http://www.mintek.co.za/wp-content/uploads/2014/10/The-MinfurnTM-energyefficient-carbon-furnace-2014.pdf (accessed December 14, 2015).

[55] S. Bradshaw, E. Van Wyk, J. De Swardt, Preliminary economic assessment of microwave regeneration of activated carbon for the carbon in pulp process, $\mathrm{J}$. Microw. Power Electromagn. Energy. 32 (1997) 131-144. http://cat.inist.fr/?aModele=afficheN\&cpsidt=10861378. 
[56] Condias, DIACHEM® DIAMOND ELECTRODES, (n.d.).

https://condias.de/en/products/diachem/ (accessed January 26, 2020).

[57] X.R. Lu, M.H. Ding, C. Zhang, W.Z. Tang, Comparative study on stability of boron doped diamond coated titanium and niobium electrodes, Diam. Relat. Mater. 93 (2019) 26-33. doi:10.1016/j.diamond.2019.01.010. 